\title{
The Impact of Remittances on Labor Supply: The Case of Jamaica
}

\author{
Namsuk Kim* \\ The World Bank
}

\begin{abstract}
A puzzle in the recently-stagnated economy of Jamaica is that high rates of unemployment have persisted even when real wages have been increasing. This paper examines aspects of the labor supply in an effort to understand why high rates of unemployment have existed with increasing real wages. This is a sign of a badly functioning labor market. The cross-sectional analysis suggests that remittances have some impact on labor supply, especially on labor market participation. The pseudo panel data analysis also confirms that remittances have a strong impact on labor participation but not on weekly working hours. Households with remittance income a have higher reservation wage and have reduced the supply of labor by moving out of the labor force.
\end{abstract}

Keywords: Labor Supply, Remittance, Reservation Wage JEL codes: J21, J38, H24

World Bank Policy Research Working Paper 4120, February 2007

The Policy Research Working Paper Series disseminates the findings of work in progress to encourage the exchange of ideas about development issues. An objective of the series is to get the findings out quickly, even if the presentations are less than fully polished. The papers carry the names of the authors and should be cited accordingly. The findings, interpretations, and conclusions expressed in this paper are entirely those of the authors. They do not necessarily represent the view of the World Bank, its Executive Directors, or the countries they represent. Policy Research Working Papers are available online at http://econ.worldbank.org.

* This research would not have been possible without the collaboration of my colleagues in the Jamaica Poverty Assessment Team. I give special thanks to Pedro Olinto, Errol Graham, Jaime Saavedra and Antonella Bassani for many useful comments and support. Namsuk Kim is with the Poverty and Gender Group (LCSPP), Latin America and the Caribbean Region. Email: nkim@worldbank.org. Address: MSN I8-805, World Bank, 1818 H Street NW, Washington, D.C. 20433, USA. Phone: (202) 473-2924. Fax: (202) 522-0054. 


\section{Introduction}

Jamaica is considered to have had relative success in developing a sound market economy and reducing poverty over the last decade and a half. The Jamaican economy has undergone significant changes since the beginning of the 1990s. The country has followed the regional Latin America and the Caribbean (LAC) trend and has shifted from an industrial economy to a service oriented one. The contribution of the industrial sector to national GDP fell from 40\% in 1992 to 30\% in late 1998, while the contribution of the service sector increased from 52\% to $62 \%$. ${ }^{1}$ The agriculture sector remained stable during the same period. Hence, while at the beginning of the 1990s Jamaica was relatively more oriented to the industrial sector than the average LAC country, it has converged with the rest of the region in becoming a more service oriented economy. This trend is commonly observed in industrial countries. The composition of employment across sectors followed a similar trend.

Jamaica, however, has suffered from labor market problems that are common to other small LAC countries: A shrinking labor force and high unemployment. Employment has grown slowly in the last decade and a half, and domestic labor force participation decreased during the same period. In fact, Jamaica is one of the few countries in LAC in which labor force participation rates have had a negative impact on the growth of labor supply. Also, the negative impact of net migration on the growth of labor supply in Jamaica has been one of the strongest in the region. ${ }^{2}$ Labor force participation rates have been declining steadily for both men and women in Jamaica.

Along with the declining participation rates, Jamaica has experienced double digit unemployment for most of the 1990s and the early 2000s. On average, the unemployment rate for women has been twice as high as the rate for men. Not surprisingly, femaleheaded households account for about two-thirds of the households in poverty.

The recently-stagnated economy of Jamaica poses a puzzle in that high rates of unemployment have persisted even when real wages have been increasing for more than a decade. The real wage increased from less than $\mathrm{J} \$ 900$ to more than $\mathrm{J} \$ 2,000$ during the

\footnotetext{
${ }^{1}$ World Bank (2006a)

${ }^{2}$ World Bank (2006c)
} 
period 1990-2002. ${ }^{3}$ Because no high inflation or deflation was observed in the same period, the steady increase of the nominal wage led to the steady increase of the real wage. If the labor market was functioning well in Jamaica, high wage should be shortlived if the unemployment rate is high, or vice versa.

In this paper I examine aspects of the labor supply to try to understand why high rates of unemployment have existed along with increasing real wages. This is a sign of a badly functioning labor market. The individual labor supply decision is studied to find out if remittance income has an impact on reservation wages and labor supply. Since labor power is the most important asset of the poor, employment and the functioning of labor markets should be vital items of any poverty reduction strategy.

In the next section I start with a brief background analysis of the main trends in employment and labor market participation, the evolution of wages, labor productivity and returns to education in Jamaica. I argue that the increases in real wages are not likely due to increases in productivity or to increasing returns to education. In Section 3, I look into migration and remittances more closely. I provide evidence from both cross-sectional and pseudo-panel analyses that remittances may indeed be raising the reservation wages of recipients, and argue that this may have caused the upward trend in real wages.

\section{Background: Unemployment and Real Wage Trends}

Overall employment has grown rather slowly in Jamaica since the early 1990s ( $0.3 \%$ per year). The economy's slow growth seems to be preventing new entrants to the labor force from finding jobs in Jamaica. The Jamaican labor force has in fact declined between 1996 and 2001, suggesting a withdrawal of workers from job seeking, at least in the domestic labor market. Unemployment rates also remain around $10 \%$ in most of the time during 1990-2002 as in Figure 1.

The high unemployment deteriorates the poverty rate in Jamaica. The higher unemployment amongst women (16 percent compared with 7 for males in average between 1990 and 2002) in part explains the strong gender dimension to poverty. Femaleheaded households account for about two-thirds of the households in poverty and

\footnotetext{
${ }^{3}$ Monthly salary in J\$ divided by CPI (base year 1995). See Figure 1.
} 
generally show a higher incidence of poverty in all the surveys since 1989. In 2002, the per capita consumption in female-headed households $(\mathrm{J} \$ 7,795)$ was nearly 22 percent lower than in male headed households.

Despite persistent high unemployment rates, average real wages and salary earnings in Jamaica have risen strongly in the late 1990s. As seen in Figure 1, between 1990 and 2002, average real weekly earnings in Jamaican dollars have more than doubled (a compound growth rate of 16 percent per year). In US dollars, earnings have also almost doubled.

Figure 1 Unemployment Rate(\%) and Average Annual Real Wage per Worker (J\$/CPI), 1990-2002

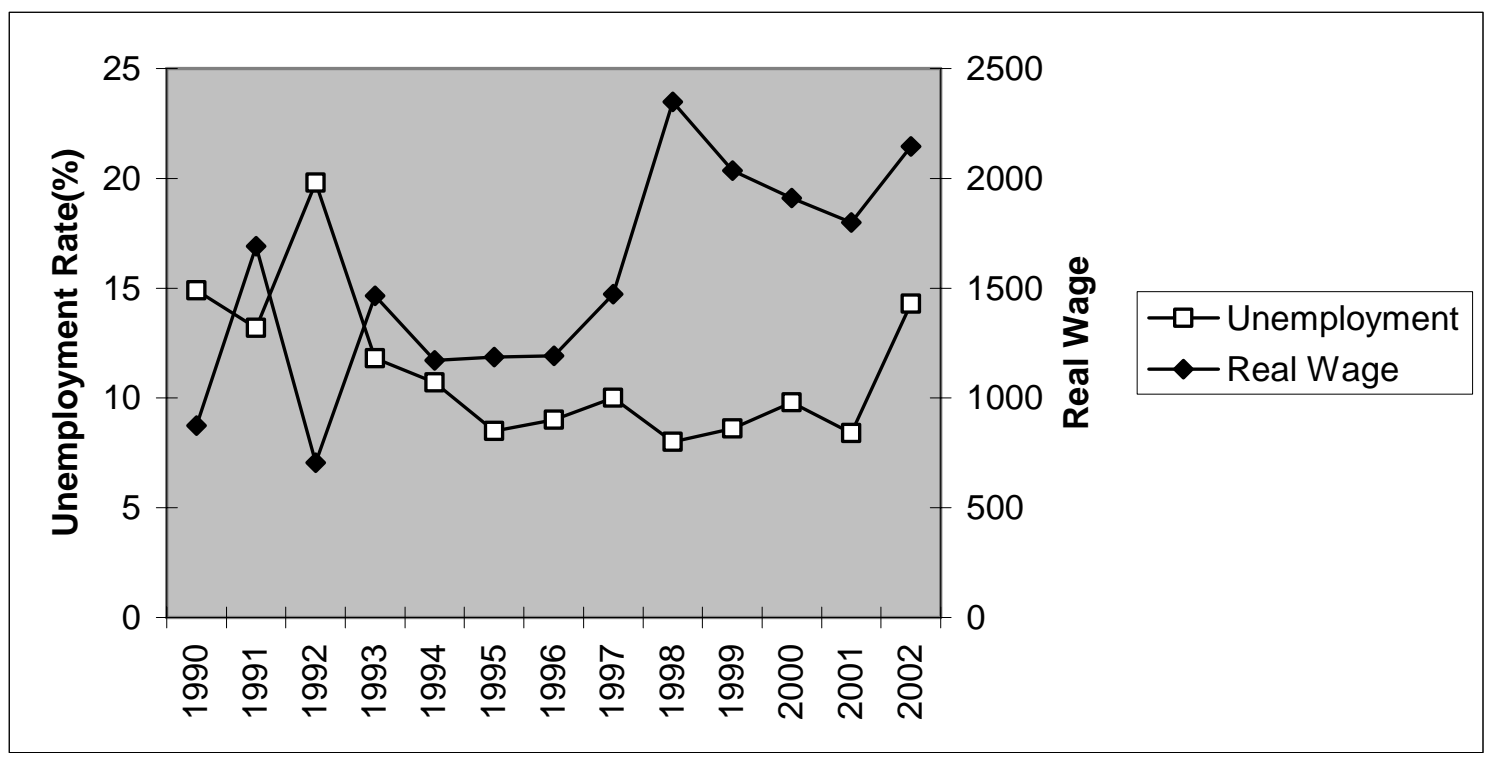

Source: Author's calculation from the survey. CPI is from the Central Bank of Jamaica. Note: The base year for CPI is 1995.

What are the causes of the growth in real wages under persistent unemployment in Jamaica? Labor productivity growth does not seem to be one of them. There is no evidence of a significant increase in average labor productivity in the industrial, agriculture or service sectors. ${ }^{4}$ Nationally, productivity seems to be in fact declining, not increasing.

This drop in productivity is likely associated to a decline in the level of education of the labor force. The average years of education of the labor force by birth cohort has

\footnotetext{
${ }^{4}$ Labor productivity (GDP/Employees) by sector is almost flat from 1995 to 2003. See World bank(2006a) and World Bank (2006c).
} 
decreased significantly from 5.6 years in 1995 to 4.5 in $2002 .{ }^{5}$ There has been a slight reversion of this trend between 2000 and 2002, but not enough to offset the losses observed during the second half of the 1990s. Emigration to the United States, Canada and the United Kingdom is likely to have played an important role in this decline in the average education level of the labor force, since more schooled and skilled workers the ones more likely to emigrate. ${ }^{6}$

Increasing returns to education are also not likely to be behind the growth in real wages. The rate of return of formal education has been high in Jamaica, leaving very little room to increase further. I rely on pooled regression to investigate the return of education on wage earnings using the LFS data from 1995 to 2002. Table 1 reports the result of the pooled Mincer regression and the regressions by gender. ${ }^{7}$ The coefficient estimates for Years of Education are positive and statistically significant for all three regressions and the returns to education are bigger for women. The returns to education in Jamaica are substantially high in the international standard. The average returns to education in Jamaica (11.7\%) are among the countries with highest returns to education in LAC and returns are higher than most OECD countries. ${ }^{8}$

\section{Table 1 Log Real Wage Mincer Regression (1995-2002)}

\begin{tabular}{lccc}
\hline & Total & Female & Male \\
\hline Years of Education & 0.117 & 0.143 & 0.100 \\
& $(29.86)^{\star \star}$ & $(24.34)^{\star \star}$ & $(19.53)^{\star \star}$ \\
Years of Potential Experience & 0.009 & 0.008 & 0.011 \\
& $(13.38)^{\star \star}$ & $(7.32)^{\star \star}$ & $(12.63)^{\star \star}$ \\
Urban & 0.161 & 0.166 & 0.186 \\
& $(9.43)^{\star \star}$ & $(6.84)^{\star \star}$ & $(8.03)^{\star \star}$ \\
Constant & 4.388 & 4.037 & 4.616 \\
& $(101.69)^{\star \star}$ & $(59.91)^{\star \star}$ & $(84.46)^{\star \star}$ \\
Observations & 9614 & 4634 & 4980 \\
R-squared & 0.11 & 0.14 & 0.10 \\
\hline
\end{tabular}

Note: Absolute value of t-statistics in parentheses

* significant at $5 \%$ level; ** significant at $1 \%$ level

While returns to education appear to have been increasing in most countries in the LAC region, the same is not happening in Jamaica. While returns to formal schooling

\footnotetext{
${ }^{5}$ The average years of education of all 20 years olds who are in the labor market in each year. World bank(2006c)

${ }^{6}$ Mishra (2006)

${ }^{7}$ The time trend and location effects are controlled out.

${ }^{8}$ See World Bank (2006c) for comparison.
} 
have historically been very high (12\% in average) in Jamaica circa 1990, they have recently dropped $10 \%$ in 1990 to $7 \%$ in 1999, recovering somewhat in the new millennium. ${ }^{9}$ Decreasing returns to education is perhaps a symptom that after reaching almost universality in primary and secondary enrollments, Jamaica is now focusing in improving the quality of its schools. ${ }^{10}$

Increasing wage with high unemployment suggests that labor markets are not working efficiently in capturing the excess labor available, and/or reservation wages in the work force are too high relative to productivity. The latter hypothesis would be true if, for instance, the labor force is ageing significantly, in which case the average reservation wage of the labor force would be increasing because of dropping willingness to work. In this case, employers would agree to pay a premium for experienced workers given that the supply of newly educated young workers is getting relatively thinner.

There is some evidence that the labor force is indeed aging in Jamaica. The share of young workers under 35 decreased from $47 \%$ in 1990 to $42 \%$ in 2002, and the average age of labor force has consequently increased by $6 \%$, from 36.2 to 38.5. ${ }^{11}$ Not surprisingly, Jamaica has the oldest labor force in the LAC region. ${ }^{12}$ This phenomenon is also likely to be caused by the high levels of emigration to the US and the UK.

Growth of wages in excess of productivity has been a major factor in the loss of export competitiveness, particularly in apparel exports in Jamaica. ${ }^{13}$ Therefore, to design effective policies to increase labor productivity and employment in Jamaica, it is crucial to understand the role of factors that may increase reservation wages in excess of productivity. In the next section I consider the role of remittances in widening the wedge between productivity and reservation wages.

\footnotetext{
${ }^{9}$ Psacharopoulos and Patrinos (2004), World bank(2006c)

${ }^{10}$ Approximately $80 \%$ of Jamaican adults have now a secondary or higher level of formal education. PIOJ and STATIN, various issues.

${ }^{11}$ World Bank(2006c)

12 IDB (2003)

${ }^{13}$ World Bank (2005)
} 


\section{Empirical Analysis of Remittances and Labor Supply in Jamaica}

\section{A. Remittances}

For every three Jamaicans living in Jamaica, there is at least one Jamaican living abroad. In other words, at least $25 \%$ of Jamaican citizens currently live overseas, mostly in the United States, Canada and the United Kingdom. The rate of population growth of legal Jamaicans in the US is almost twice as high as the population growth in Jamaica (1.5\% versus $0.8 \%$, respectively). While the inflow of Jamaicans into the US, Canada and the UK has decelerated somewhat in the last ten years, it is still ranging around $0.7 \%$ of the country's population. ${ }^{14}$

Not surprisingly, Jamaica is one of the countries in the LAC region with the highest percentage of households receiving remittances. The proportion of remittances to total household income has also been increasing. In the early 1990s remittances represented about $2 \%$ of total household income. By the early 2000s, they accounted for more than $6 \%$. On average, about a quarter of all Jamaicans households received some remittances between 1995 and 2002. It is interesting to note that while the percentage of households receiving remittances has decreased slightly since 1995, the ratio of remittances to total income has in fact increased. ${ }^{15}$

Table 2 shows selected statistics of recipient households. ${ }^{16}$ The average amount of monthly household remittance reaches up to US\$250 in 2001 which is a very significant amount of additional income to households. Remittances recipients are less likely to be headed by males, although the difference of share of male household heads between remittance recipients and non-recipients has decreased gradually. This fact suggests that male heads of households tend to migrate more than female heads.

Notice that household heads that received remittances, male or female, tend to work fewer hours than non recipient heads. This effect seems larger for female heads of households. A simple tabulation in Table 2 shows that remittances may have some negative impact on the labor supply in terms of weekly working hours of employees.

\footnotetext{
${ }^{14}$ IDB (2003), World Bank(2006c)

${ }^{15}$ World Bank (2006b).

${ }^{16}$ Statistics for all years are available from the author.
} 
Table 2 Selected Statistics of Remittance Recipient Households in Jamaica (1995-2002, selected years)

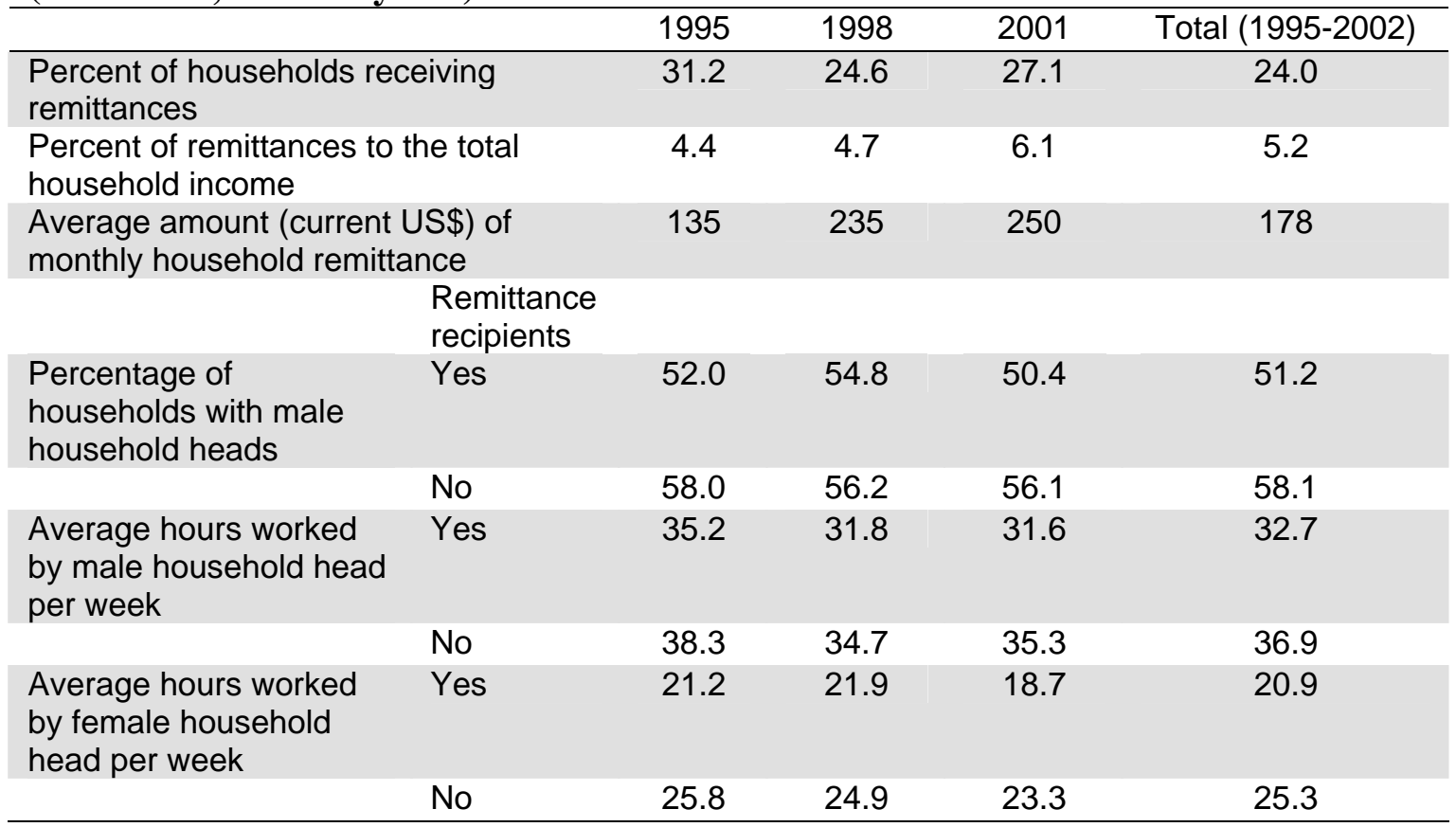

There is the hypothesis that high levels of remittances are hurting Jamaica's competitiveness because they raise the reservation wages of recipients and the equilibrium real wages in the labor market. This hypothesis follows a common conjecture that the remittances have a negative impact on the labor supply of recipient households. There are very few studies that explicitly investigate the relationship between labor supply and remittances. One exception is the study on Nicaragua by Funkhouser (1992). He found that an increase in remittances would have a negative impact on labor force participation but also a positive impact on self-employment. His study indicates that remittances change the distribution of employment in sectors. Rodriguez and Tiongson (2001) conducted a same exercise using household level data in Manila in 1991. They find remittances decrease labor participation of recipient households. A recent study by Acosta (2006) using El Salvador data shows that remittances can increase the household budget and reduce liquidity constraint problems, allowing more consumption and investment. After controlling for household wealth and using selection correction techniques, remittances are negatively related to child labor and adult female labor supply, while on average adult male labor force participation remains unaffected. That additional income derived from migration increases girls’ education and reduces women's labor 
supply, with no major impact on activity choice for males 15 years or older, suggests the presence of gender differences in the use of remittances across (and possibly within) households.

\section{B. Data}

I mainly use two household level data sets in this paper: Survey of Living Conditions (SLC) and Labor Force Survey (LFS). The SLC is the annual nationwide survey that is implemented to establish baseline measures of household characteristics and then to monitor the impact of government programs on health, education and nutrition. The SLC includes detailed information on the total amount of expenditure for food and non-food items, total amount of income from the sources other than labor. The SLC is linked to the LFS to have both living condition and labor information for the same individual. The sample size is about 2,000 households and 7,000 individuals each year. ${ }^{17}$

In the annual LFS, each member of the household is asked questions regarding his or her employment status. Employed persons are asked about hours worked, work experience, training, education, employment status and gross average income over the last twelve months. Unemployed persons are asked the duration of and reason for their unemployment, the job search, work experience, training, education, employment status, and income. Persons outside the labor force were asked about previous work experience, training, education, employment status, and income. ${ }^{18}$

Jamaica's SLC and LFS do not provide a longitudinal individual or household data that would be needed to study the effect of remittances on labors decisions over time. However, the data retains the same geographical clusters in the sample for three or four years. In the same cluster, the exactly same households are sampled every year. Although it is not possible to trace each household's behavior over time, we can trace the aggregate indicators of households at the cluster level because the member households in the cluster do not change over time as long as the cluster remains effective in the survey. A pseudopanel data can be constructed from the indicators at the cluster level over time, using the clusters as the new unit of the sample.

\footnotetext{
${ }^{17}$ World Bank (2002)

${ }^{18}$ PIOJ and STATIN, various issues
} 
I estimate the impact of remittances on labor supply using a cross-sectional analysis in each year, and also a cluster level pseudo-panel data model for the whole sample time period.

\section{Empirical Specification}

Households solve a dynamic programming problem regarding consumption and labor supply depending on remittance and real wage as in Equation 1:

\section{Equation 1 Household Level Structural Model}

$\max E_{t} U\left(L_{i j t}, C_{i j t} ; \theta\right) \quad$ s.t. $A_{i j, t+1}=(1+r) A_{i j t}+w_{i t} L_{i j t}+R_{i j t}-C_{i j t}$

where

$L_{i j t}=$ Labor supply of cluster $\mathrm{i}$, household j at time $\mathrm{t}$

$C_{i j t}=$ Consumption of cluster $\mathrm{i}$, household $\mathrm{j}$ at time $\mathrm{t}$

$A_{i j t}=$ Capital of cluster $\mathrm{i}$, household jat time $\mathrm{t}$

$w_{i t}=$ Real wage of cluster $\mathrm{i}$ at time $\mathrm{t}$

$R_{i j t}=$ Remittance income of cluster $\mathrm{i}$, household $\mathrm{j}$ at time $\mathrm{t}$

$\theta=$ set of parameters

Suppose $\left(L_{i j t}^{*}, C_{i j t}^{*}\right)$ solves the problem. The labor supply and consumption schedule should depend on the current and past remittances and real wages, and also future expectation of remittances and real wages. Now we can define an aggregate level labor indicator, for instance, cluster level average labor supply as follows:

$L_{i t}^{*}=\frac{1}{N_{i t}} \sum_{j} L_{i j t}^{*}=L_{i j t}^{*}\left(w_{i}, R_{i 1}, R_{i 2}, \cdots, R_{i J} ; \theta\right)$ 
where

$N_{i t}=$ Number of households in cluster i at time $\mathrm{t}$

$w_{i}=$ vector of wage in cluster $\mathrm{i}$ across time

$R_{i j}=$ vector of remittances of household $\mathrm{j}$ in cluster i across time

$=\left[R_{i j 0}, R_{i j 1}, \cdots, R_{i j t}, E_{t}\left(R_{i j t+1}\right), E_{t}\left(R_{i j t+2}\right), \cdots\right]$

The cluster level labor supply will depend on the real wage and the distribution of expected and realized remittances across time and households. If the households form an expectation of the future remittance based on the past realization of remittances, the cluster labor supply will be a function of remittances of all households for time zero to t. If the future remittances follow a random walk process, the best expected value of future remittance will be the current remittance income. In such a case, the cluster level labor supply should depend only on the distribution of current remittances across households.

\section{Equation 2 Cluster Level Reduced Form Model}

$$
L_{i t}=\beta_{0}+\beta_{1} R 1_{i t}+\beta_{2} R 1_{i t-1}+\beta_{3} R 1_{i t-2}+\beta_{4} R 2_{i t}+\beta_{5} R 3_{i t}+\beta_{6} w_{i t}+\beta_{7} X_{i t}
$$

where

$L_{i t}=$ Labor supply of cluster $\mathrm{i}$ at time $\mathrm{t}$

$w_{i t}=$ Real wage of cluster $\mathrm{i}$ at time $\mathrm{t}$

$R 1_{i t}=$ First moment of remittance income distribution of cluster $\mathrm{i}$ at time $\mathrm{t}$

$R 2_{i t}=$ Second moment of remittance income distribution of cluster $\mathrm{i}$ at time $\mathrm{t}$

$R 3_{i t}=$ Third moment of remittance income distribution of cluster $\mathrm{i}$ at time $\mathrm{t}$

$X_{i t}=$ Characteristics of cluster $\mathrm{i}$ at time $\mathrm{t}$

Equation 2 describes the derived reduced form of cluster level labor supply. The cluster level labor supply depends in the current and past distribution of remittances within the cluster. I use first to third moment of remittance income in order to proxy the distribution of remittances. $\mathrm{X}$ includes other control variables at the cluster level, such as the average education level, average household size, average expenditure, standard 
deviation of expenditure, percentage of food stamp recipients, share of male headed household and share of poor people. ${ }^{19}$

\section{Result and Discussion}

First, a simple cross sectional study gives an evidence of a negative impact of remittances on the labor market participation. In 2002, the correlation of remittance and labor market participation at the individual level is $-0.036 .{ }^{20}$ The result suggests that any individual who receives remittances from abroad is $3.6 \%$ less likely to participate in the labor market. The estimates for correlation coefficient are robust across years, and the sign of the coefficient never changes.

However, the weekly hours worked of employed people are not significantly correlated with remittance as seen in the scatter plot of individual level remittance and weekly working hours (Figure 2). There are some mass points around 40, 50 and 60 hours, and the working hours for most workers are fixed at 40, 50 or 60 hours per week regardless of the level remittance income. It suggests that the remittance income is strongly correlated with the labor market participation decision, but not with how many hours the employees would work.

\footnotetext{
${ }^{19}$ Poor people are identified by national poverty line defined by PIOJ. See World Bank (2006c).

${ }^{20}$ The result is significant at 5\% confidence level.
} 
Figure 2 Weekly Working Hours and Remittances (Individual Level, 2002)

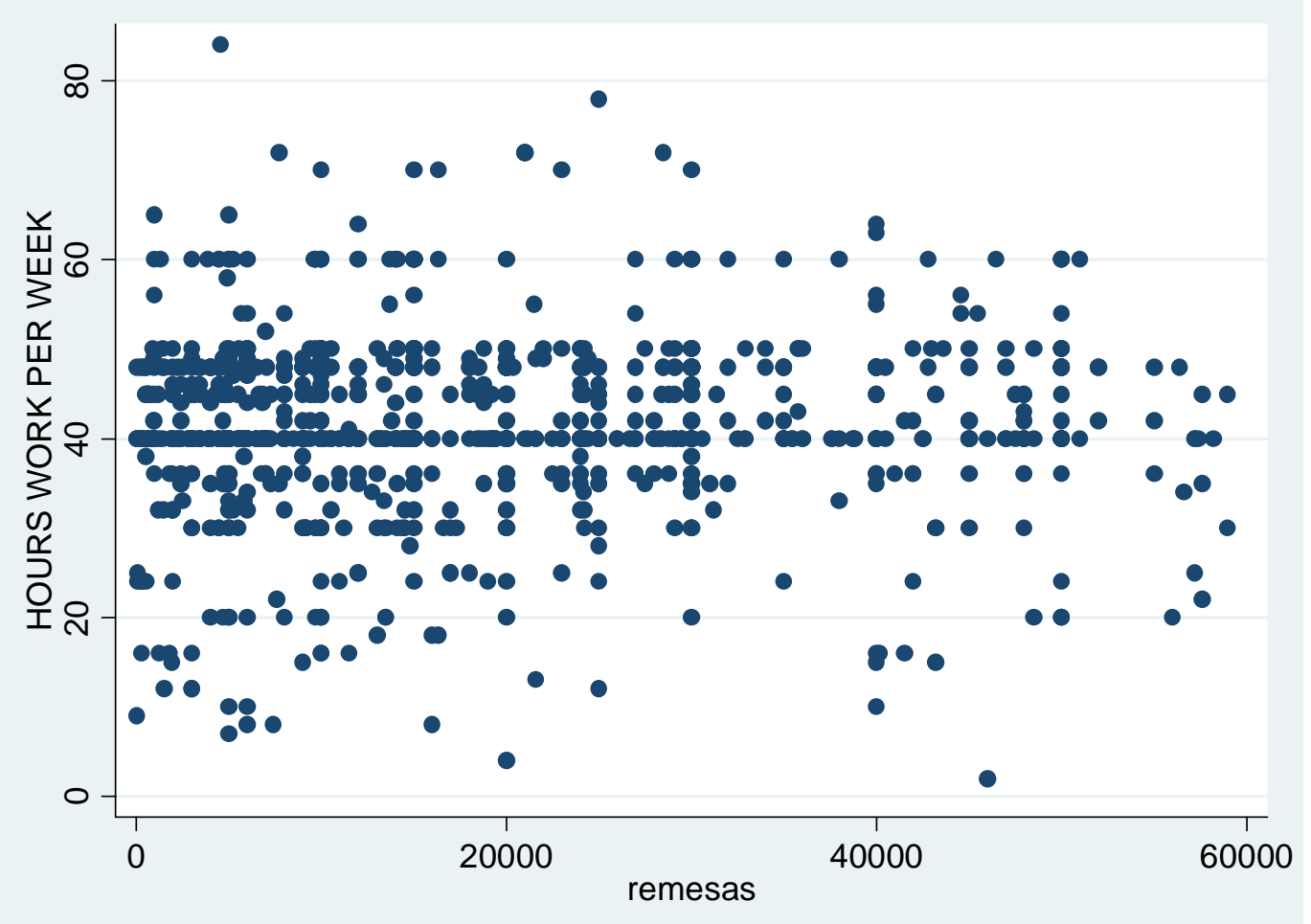

Source: Author's calculation from SLC and LFS.

The panel data analysis at the cluster level also confirms a negative effect of remittances on the labor market participation but not a strong effect on the hours worked of employees at the cluster level. Table 3 reports the result from the fixed effect regression of cluster level labor force participation (LFP) and weekly working hours (WWH) from 1995 to $2002 .^{21}$

The coefficient estimate for the current monthly remittance in the Specification I is -0.037 and statistically significant at $5 \%$ confidence level. The past remittances at time t-1 and t-2 have negative impact as well, but they are not statistically different from zero. Neither the second moment (standard deviation) and third moment (skewness) of remittances within the cluster has significant impact of current labor force participation decision. Coefficient estimates associated to other control variables are not statistically significant. The regression result from Specification I suggests that the labor force

\footnotetext{
${ }^{21}$ The Arellano-Bond linear panel regression will be better to take care of specification errors and endogeneity problem for this type of estimation. However, I have only three or four observations per each cluster without changing the households in the same cluster. For the regression using the short time period, Arellano-Bond estimation performs poorly comparing to the standard fixed effect regression, because the former needs to construct a difference variable using observations for two consecutive time periods.
} 
participation rate at the cluster level is negatively linked to the current value of remittances, but rather unaffected over time by change of cluster characteristics. Notice that the coefficient estimate for remittances is almost the same as the correlation coefficient of cross sectional relationship between remittances and labor market at the individual level, because other control variables do not explain the labor market participation.

In the Specification II, higher moments of remittance distribution are excluded from the estimation. The effect of current remittance on the labor force participation is .022 and it is a bit lower than in the Specification I. Other control variables do not have strong explanatory power. The coefficient estimate for remittances has a reduced magnitude but still retains a negative sign with a statistical significance.

Specification III and IV report that remittances do not have a significant impact on the labor supply of employed people in the panel analysis as in cross-section analysis. Specification III and IV use the weekly working hours per household as the dependent variable and only the employed workers are included in this estimation. The coefficient estimates for remittances are negatively signed but not statistically significant. 
Table 3 Fixed Effect Regression of Labor Force Participation Rate (LFP) and Weekly Working Hours (WWH) at the Cluster Level, 1995-2002

\begin{tabular}{|c|c|c|c|c|}
\hline & $\begin{array}{c}\text { LFP } \\
\text { I }\end{array}$ & $\begin{array}{c}\text { LFP } \\
\text { II }\end{array}$ & $\begin{array}{c}\text { WWH } \\
\text { III }\end{array}$ & $\begin{array}{l}\text { WWH } \\
\text { IV }\end{array}$ \\
\hline$\overline{\text { Remittance }}$ & $\begin{array}{l}-0.037 \\
(0.018)^{\star \star}\end{array}$ & $\begin{array}{l}-0.022 \\
(0.047)^{\star \star}\end{array}$ & $\begin{array}{l}-0.059 \\
(0.300)\end{array}$ & $\begin{array}{l}-0.022 \\
(0.594)\end{array}$ \\
\hline Remittance (t-1) & $\begin{array}{l}-0.020 \\
(0.220)\end{array}$ & $\begin{array}{l}-0.012 \\
(0.372)\end{array}$ & $\begin{array}{l}-0.024 \\
(0.692)\end{array}$ & $\begin{array}{l}-0.023 \\
(0.650)\end{array}$ \\
\hline Remittance (t-2) & $\begin{array}{l}-0.009 \\
(0.534)\end{array}$ & $\begin{array}{l}-0.006 \\
(0.603)\end{array}$ & $\begin{array}{l}0.005 \\
(0.926)\end{array}$ & $\begin{array}{l}0.024 \\
(0.556)\end{array}$ \\
\hline Standard deviation of remittance & $\begin{array}{l}0.000 \\
(0.247)\end{array}$ & & $\begin{array}{l}0.000 \\
(0.283)\end{array}$ & \\
\hline Skewness of remittance & $\begin{array}{l}-0.019 \\
(0.235)\end{array}$ & & $\begin{array}{l}-0.117 \\
(0.042)^{\star \star}\end{array}$ & \\
\hline Real wage & $\begin{array}{l}0.010 \\
(0.741)\end{array}$ & $\begin{array}{l}0.007 \\
(0.816)\end{array}$ & $\begin{array}{l}-0.100 \\
(0.364)\end{array}$ & $\begin{array}{l}-0.065 \\
(0.545)\end{array}$ \\
\hline Average education & $\begin{array}{l}0.020 \\
(0.433)\end{array}$ & $\begin{array}{l}0.009 \\
(0.680)\end{array}$ & $\begin{array}{l}0.319 \\
(0.001)^{\star \star \star}\end{array}$ & $\begin{array}{l}0.321 \\
(0.000)^{\star \star \star}\end{array}$ \\
\hline Average Household Size & $\begin{array}{l}-0.032 \\
(0.230)\end{array}$ & $\begin{array}{l}-0.040 \\
(0.066)^{*}\end{array}$ & $\begin{array}{l}0.150 \\
(0.129)\end{array}$ & $\begin{array}{l}0.083 \\
(0.303)\end{array}$ \\
\hline Mean expenditure & $\begin{array}{l}-0.048 \\
(0.780)\end{array}$ & $\begin{array}{l}-0.033 \\
(0.824)\end{array}$ & $\begin{array}{l}-0.055 \\
(0.930)\end{array}$ & $\begin{array}{l}0.380 \\
(0.501)\end{array}$ \\
\hline Standard deviation of expenditure & $\begin{array}{l}-0.106 \\
(0.662)\end{array}$ & $\begin{array}{l}-0.139 \\
(0.511)\end{array}$ & $\begin{array}{l}-0.533 \\
(0.547)\end{array}$ & $\begin{array}{l}-0.579 \\
(0.466)\end{array}$ \\
\hline Percentage of food stamp recipients & $\begin{array}{l}-0.037 \\
(0.701)\end{array}$ & $\begin{array}{l}0.026 \\
(0.771)\end{array}$ & $\begin{array}{l}0.024 \\
(0.947)\end{array}$ & $\begin{array}{l}0.360 \\
(0.277)\end{array}$ \\
\hline Share of male headed household & $\begin{array}{l}-0.025 \\
(0.658)\end{array}$ & $\begin{array}{l}-0.025 \\
(0.587)\end{array}$ & $\begin{array}{l}-0.087 \\
(0.668)\end{array}$ & $\begin{array}{l}-0.005 \\
(0.978)\end{array}$ \\
\hline Share of poor people & $\begin{array}{l}-0.165 \\
(0.163)\end{array}$ & $\begin{array}{l}-0.156 \\
(0.141)\end{array}$ & $\begin{array}{l}0.057 \\
(0.895)\end{array}$ & $\begin{array}{l}0.263 \\
(0.507)\end{array}$ \\
\hline Constant & $\begin{array}{l}1.417 \\
(0.002)^{\star \star \star}\end{array}$ & $\begin{array}{l}1.218 \\
(0.000)^{\star \star \star}\end{array}$ & $\begin{array}{l}4.118 \\
(0.015)^{\star \star}\end{array}$ & $\begin{array}{l}3.335 \\
(0.009)^{\star \star \star}\end{array}$ \\
\hline Obseı & 206 & 222 & 206 & 222 \\
\hline Number of cluster & 120 & 123 & 120 & 123 \\
\hline R-squared & 0.285 & 0.239 & 0.285 & 0.239 \\
\hline
\end{tabular}

$\mathrm{p}$ values in parentheses

* significant at 10\%; ** significant at $5 \%$; ** significant at $1 \%$

In summary, the remittance income has a negative impact on the labor market participation both in the cross-section analysis at the individual level and the panel analysis at the cluster level. However, the effect of remittances is not strong for the labor supply of employed workers. The empirical analysis reports that people with higher remittances are more likely to have a higher reservation wage, resulting in moving out of labor force, or being less enthusiastic about finding jobs. 


\section{Conclusion}

In many small countries in the Caribbean, the shrinking labor force and high unemployment are among the main problems that governments face. This paper shows that the situation may be the same, but the causes may be strikingly different. The typical diagnosis for these problems is associated with the demand side of the labor market, such as job creation, investment climate, regulation and governance, and so on. This paper studies various aspects of the supply side of the labor market to find factors that prevent Jamaica from achieving lower unemployment rates.

The empirical analysis in this paper examines the effect of remittance income on the labor supply of households and some evidence was found to confirm that remittances contribute to high real wages while high unemployment persists. The cross-sectional analysis suggests that remittances have some impact on labor participation but little or none on the weekly working hours of employees. The pseudo-panel data analysis confirms the result that remittances have a strong impact on labor participation but not on weekly working hours. Households with a remittance income have a higher reservation wage and reduce labor supply by moving out of the labor force.

Increased remittance flows may negatively affect the competitiveness of the Jamaican economy. As suggested by the results discussed above, they may increase reservation wages and reduce labor supply. Sparked from the channel of the labor market, they can also affect the real economy, exports, investment and growth as shown in Bussolo and Medvedev (2006). World Bank (2006c) examines these complicated links and the direction and magnitude of the changes in the case of Jamaica. The results in this paper call for studies tracing these effects in other economies, because remittances are one of the major issues for development research (World Bank, 2006b). 


\section{Reference}

Acosta, Pablo (2006), " Labor supply, school attendance, and remittances from international migration: the case of El Salvador," Policy Research Working Paper 3903, World Bank

Adams, Richard H. Jr. (2003), "International migration, remittances, and the brain drain: a study of 24 labor exporting countries," Policy Research Working Paper 3069, World Bank

Burgess, Robert and Vikram Haksar (2005), "Migration and Foreign Remittances in the Philippines," IMF Working Paper

Bussolo, Maurizio and Denis Medvedev (2006), "Do remittances have a flip side? A general equilibrium analysis of remittances, labor supply responses and policy options for Jamaica," mimeo

Chami, Ralph, Connel Fullenkamp, and Samir Jahjah (2003), "Are Immigrant Remittance Flows a Source of Capital for Development?" IMF Working Paper

Downes, A., N. Mamingi and R. Antoine (2004), "Labor Market Regulation and Employment in the Caribbean," in Law and Employment - Lessions from latin America and the Caribbean by J. Heckman and C. Pages

Funkhouser, Edward (1995), Remittances from International Migration: A Comparison of El Salvador and Nicaragua, Review of Economics and Statistics

Goldring, Luin (2004) Family and Collective Remittances to Mexico: A Multidimensional Typology, Development and Change

Inter-American Development Bank (IDB, 2003), Social Panorama of Latin America

Jacoby, Hanan G. (1997), "Self-Selection and the Redistributive Impact of In-Kind Transfers: An Econometric Analysis," The Journal of Human Resources

Kathuria, Sanjay et al (2003), Jamaica: The Road to Sustained Growth, World Bank

Matshe, Innocent, and Trevor Young (2004), “Off-Farm Labor Allocation Decisions in Small-Scale Rural Households in Zimbabwe” Agricultural Economics 30, pp. 175-186.

Mishra, Prachi (2006), " Emigration and Brain Drain: Evidence from the Caribbean," IMF Working Paper 
Planning Institute of Jamaica (PIOJ) and Statistical Institute of Jamaica (STATIN), Jamaica Survey of Living Conditions, various issues

Psacharopoulos, George and Harry Patrinos (2004), "Returns to Investment in Education: A further Update," Education Economics

Rodriguez, Edgard R. and Erwin R. Tiongson (2001), "Temporary Migration Overseas and Household Labor Supply: Evidence from Urban Philippines," International Migration Review, pp. 708-725

Statistical Institute of Jamaica (STATIN), The Labor Force, various issues

World Bank (2002), Basic Information on Jamaica Survey of Living Conditions (2005), World Development Indicators (2006a), World Development Indicators (2006b), The Development Impact of Remittances in Latin America (2006c), Jamaica Poverty Assessment: Breaking the Cycle of Unemployment, Vulnerability and Crime

Zarate-Hoyos, G. (2004), "Consumption and Remittances in Migrant Households: Toward a Productive Use of Remittances," Contemporary Economic Policy 